\title{
Factors Enhancing Positive Performance of Students from Single Parent at Alfagems Secondary School
}

\author{
Neema Adam Rubamande ${ }^{1 *}$, Marcel Mukadi \\ ${ }^{1}$ Department of Education, Faculty of Arts and Social Science, Jordan University College, Morogoro, Tanzania \\ ${ }^{2}$ Department of Theology, Jordan University College (JUCo), Morogoro, Tanzania \\ Email: *neemasuzy8@gmail.com, mukadimarcel@yahoo.fr
}

How to cite this paper: Rubamande, N. A., \& Mukadi, M. (2021). Factors Enhancing Positive Performance of Students from Single Parent at Alfagems Secondary School. Open Journal of Social Sciences, 9, 185-192. https://doi.org/10.4236/jss.2021.99013

Received: May 28, 2021

Accepted: September 4, 2021

Published: September 7, 2021

Copyright $\odot 2021$ by author(s) and Scientific Research Publishing Inc. This work is licensed under the Creative Commons Attribution International License (CC BY 4.0).

http://creativecommons.org/licenses/by/4.0/ (c) (i) Open Access

\begin{abstract}
The purpose of the study was to investigate the factors enhancing positive performance of students from single parent families in secondary schools specifically Alfagems secondary school, the case study in Morogoro Municipality. The study employed both quantitative and qualitative research approach. Both purposive and random sampling techniques were used. Primary data were collected from 50 respondents who were randomly selected through interview and questionnaires. The study result revealed that positive attitude of the students towards academic matters, positive social circle, self-motivating and encouraging, counseling and guidance services as well as setting high expectations and desires in life were found to be the influencing factors enhancing good performance of students from single parents. Basing on the study findings, the researchers recommend that parents should be responsible to their children in order to ensure the good welfare of their children. Schools at all levels should have strong guidance and counseling unit to help the students in need of special attention.
\end{abstract}

\section{Keywords}

Single Parent, Students, Positive Performance

\section{Introduction}

Parents are the first point of contact of children. When both parents are present, it implies that the child would derive most care (Ortese, 1998). However, when one of the parent is absent in a child's life, a gap is created as the child would lose the support that would have emanated from that parent. Single parenting 
results from divorce, separation of various kinds, having children out of wedlock or death of one spouse which leaves the roles in the hands of a single parent (Ortese, 1998). Globally, one-quarter to one-third of all families are headed by single-mothers. Developed countries, in particular, experience an increase in single-parent families as divorce becomes more common (Ponzetti, 2003). United Kingdom has over one million single-parent families; this gives one family in seven to be a single-parent family. The number of single-parent families is still increasing in recent years. Most single-parent families come into being as a consequence of marital breakdown, separation or divorce, but the increasing proportions are the result of births out of wedlock (Smith, 2008).

In Tanzanian context it was reported that divorce cases have increased and in somewhat it continues to affect a big number of children, as result increase high number of street children, law-breaking teenage, pregnancies in girls as well as high rate of school dropout (Kimwaga, 2000). Parental separation is common in Tanzania rather than legal divorces followed by a big numbers of marital dissolution complaints in social welfare departments increasing day to day (RITA, 2007). The Tanzania Media Women Association (TAMWA) reported that Magomeni court in Dar-es-salaam received 118 divorce cases in 1997; they rose to 422 cases by the year 1999. Divorce cases in the country may even be higher, but it might be other divorce cases which are not reported at all. The Women Legal Aid Centre (WLAC) annual report showed that organization has received a total of 2390 cases in 2000 and raised up to 4349 cases in 2006 (TAMWA, 2009).

That is to say if divorce cases are increasing to that extent the growing number of single parent children will increase too and obviously the female become the victims and responsible for taking care for their children as a mother and most of them find it difficult to remarry unlike men. Serious marital conflicts have been reported every three months in Dar es-salaam alone (Jonathan, 2004). Furthermore, the increased number of people has been seeking assistance with marital conflict over the few years in Tanzania (Daniel, 2010).

A single parent family is becoming a societal challenge as its number is increasing rapidly for instance in Tanzanian context it was reported that divorce cases have increased and in somewhat it continues to affect a big number of children, as result increase high number of street children, law-breaking teenage, pregnancies in girls as well as high rate of school dropout (Kimwaga, 2000). Parental separation is common in Tanzania rather than legal divorces followed by a big numbers of marital dissolution complaints in social welfare departments increasing day to day (RITA, 2007).

Despite parents being responsible for the psychological, emotional welfare, educational and career development of their children, divorce and separation of various kinds or death of one spouse may leave the role in the hands of single parent. Many children are being reared by single-mothers, who seem to struggle making ends meet living below the poverty line; though some few women are rich the majority are poor. Perhaps, single-mothers and fathers do not have as 
much time as required to participate fully in their children's schooling, thus adding to the problems for children of single-parent families (Ferrell, 2009). Parents are the child's first role model. Children behave, react and imitate same as their parents. Parents play important role in encouraging and motivating their kids to learn. Good parental support helps child to be positive, healthy and good life long learner. Children acquire skills at the very early stage of their life if the parents are responsive and understanding (Kolambe, 2016). Children in single-parent households have a lower standard of living than do children in two parent households (Amato, 2010).

Different studies (Amofa, 2013; Mrinde, 2014; Malima \& Akech, 2016), have been conducted in different parts of the country and the world at large about the effects of single-parent on the effects of single parenting on students' academic performance in secondary schools. However, despite all these efforts regarding the effects of single-parent on students' performance explained by different scholars in different parts of the continent but none of them managed to inform the public about the factors enhancing positive performance of students from single parent in Morogoro Municipality.

Therefore, researchers investigated the factors enhancing positive performance of students from single parent families a case of Alfagems secondary school in Morogoro Municipality. Alfagems secondary like other Secondary schools in Tanzania comprises students from all family backgrounds including students from single parent families. This study, therefore, intended to study the extent to which the changing family structure by having a single-parent affects the academic performance of students from such families by investigating the factors enhancing positive performance of students from single parent families.

\subsection{The Theoretical and Analytical Framework}

\section{Structural-Functionalism}

The structural-functionalism emphasizes on the formal ordering of parts and their functional interrelations as contributing to the maintenance needs of a structured social system. This theory of structural functionalism is closely associated with the work of Parsons (1951) who argued that the family performs a number of functions within the society. According to him to functions are crucial; firstly, the socialization of new members into the appropriate values, norms and standards of society indicating that the role of the family is to make sure that independence and a motivation to achieve is to instill the children's behaviours. Second, to stabilize adult behaviour through marriage serves as the remedy to the emotional stress and tensions of everyday life. Despite that the theory identifies the differentiation of gender roles within the family, with partners complimenting each other's roles but men were noted as performing an instrumental role while women provide the complement with their more expressive nature (Parsons, 1951). This implies that the expressive role was assigned to women because of the primary expressive attachment between mother and children. 


\section{Research Methods and Methodology}

The study was conducted at Alfagems secondary school in Morogoro Municipality which employed mixed research approach i.e., both quantitative and qualitative research approach were used. Both purposive and randomly sampling techniques were used. Primary data were collected from 50 respondents i.e., 40 single parent students and 10 parents through structured questionnaires and interview respectively. The researchers administered the questionnaires to 40 single parent students at Alfagems secondary school in Morogoro Municipality. The pilot study was conducted to ensure content validity of the research instruments which were determined by expert opinions while its reliability was empirically ascertained by test-retest procedure using 10 respondents which yielded a coefficient value $\alpha=$ 0.60 . The data collected qualitatively in this study were analyzed thematically with the use of SPSS version 20 this allowed the normality of the questionnaires.

\section{Results and Discussion}

\section{Factors for Positive Performance of Students from Single Parented Families}

In assessing the factors enhancing positive performance of students from single parent in Morogoro Municipality specifically at Alfagems secondary school the case study; researchers sought to know the contributing factors for positive performance. Students from single parents are likely to perform well in their academic level as well as high self-esteem. The researchers administered 40 questionnaires to 40 single parent students and conducted interview to 10 parents together with DEO and school heads who were key informants in this study. The respondents were required to indicate the degree of improvement they know about the contributing factors for good performance of students from single parented families. Table 1 below presents the study results.

Attitude of the Students, it was found that 11 respondents accounted to $22 \%$ strongly agreed that attitude of the students is a factors for positive performance of students from single parent in the study area. The study result implies that

Table 1. Factor's for positive performance of students from single parented families.

\begin{tabular}{ccc} 
Factors & $\begin{array}{c}\text { Frequency } \\
(\mathbf{n}=\mathbf{5 0})\end{array}$ & $\begin{array}{c}\text { Percentage } \\
\text { (\%) }\end{array}$ \\
\hline Attitude of the Students & 11 & $22 \%$ \\
Social Circle (Surrounding People) & 6 & $12 \%$ \\
Self-Motivating and Encouraging & 10 & $20 \%$ \\
Counseling and Guidance Services & 14 & $28 \%$ \\
Setting of High Expectations and Desires in Life & 9 & $18 \%$ \\
Total & 50 & $100 \%$ \\
\hline
\end{tabular}

Source: Field research, 2020. 
students with positive attitudes to his or her academic matters perform well. A large proportional of respondents about $22 \%$ suggested that students who have attitude to education are more likely to perform well in their studies. The study result is consistent with the findings of various related studies (Akinsola \& Olowojaiye, 2008; Mutai, 2011) who found that a positive attitude is a key contributor to higher performance. They further argued that attitude should not be ignored once positive attitude is formed, it can improve students' learning. This is contrary to the findings of Stone (2012) who found that students from single parents have tendencies of noticeable traits of under-nourishment, and negative attitude towards academic matters, that leads to underachievement and negative performance.

Social Circle (Surrounding People); it was found that $12 \%$ of the respondents agreed by mentioning social circle (surrounding people) i.e., friends, family and relatives at home contribute to students' positive performance in their studies in the study area. The study result is in line with the Walberg's Theory which states that, individual students' psychological attributes and the psychological environments surrounding them influence cognitive, behavioural and attitudinal learning outcomes (Reynolds \& Walberg, 1992). The theory is relevant for this study because it is an appropriate theory in explaining the reasons for positive performance of single parent students in the study area. Also, the study result is consistent with the findings of other related studies (Hoover-Dempsey et al., 2005; Redding, 2006; Nyarko, 2010) who found that the direct surroundings of the students have a noticeable influence on the students' academic performance i.e., positive performance of single parent students in this case.

Self-Motivating and encouragement, the researchers sought to establish selfmotivation is the ability to do what needs to be done, without influence from other people. It was found in this study that $20 \%$ of the respondents strongly agreed that self-motivation and encouragement is one among the factors that contribute to positive performance in their academic matters. The researchers considered self-motivation to be important variable in this study as it is related to attitude and students' academic achievement. This is study result is in line with the findings of many related studies (OECD, 2013; Mazana et al., 2019; Unamba, Okwara-Kalu, \& Ibe Georgeline, 2020) who found that there is a significant relationship exists between students' academic achievement and students' motivation and encouragement. Furthermore, Mazana et al. (2019) argued that students' behaviour is connected to students' motivation to learn that is reflected with student's actions, commitment, and performance in class. Therefore, basing on the study findings, researchers conclude that self-motivation and encouragement depends on both students' interest and desire to learn.

Counseling and Guidance Services; the study results from Table 1 above shows that, $28 \%$ agreed that counseling and guidance services from the teachers help single parent students in academic, behaviour etc. hence results into positive performance despite the challenges they are facing. This implies that teachers, counselors, educational psychologist and administrators have knowledge of 
the factors that affect children from single-parent homes results into creating good learning environment and changing students' altitude hence leads to positive performance. The study result is consistent with the findings of various related studies (Salami \& Alawode, 2000; Azuka-Obieke, 2013) who found that guidance and counseling have been introduced in secondary schools to focus on students' problems emanating from adolescence crisis.

Setting of High Expectations and Desires in Life, it was found that setting of high expectations and desires in life for students from single parent lead to positive performance. It was revealed that $18 \%$ of respondents strongly agreed setting of high expectations and desires in life is a motivation or driving force to single parent students for learning that makes them to perform well. The study result is in line with the findings of various related studies (Yunus \& Ali, 2009; Parisa, 2011; OECD, 2013) who found that academic self-esteem as a standard by which a student's judges her/himself, an estimate, a feeling, and an emotion. This self-evaluation is the single most significant key to behaviour, which affects the thinking processes, emotions, desires, values, and students' goals. The study result implies that, single parent students acquire a sense of knowledge and understanding of their desires, and goals which are associated with school activities especially academic matters that lead to positive performance.

Also, during interviews, it was revealed that the majority of single parents do not discuss hopes and dreams for child's education early and regularly as this is left to the child himself or herself to set his/her expectations and dreams/hopes. From the study area one parent said:

"... I have four children; my first born is now pursuing bachelor degree in finance. This achievement mostly came from her as I never sat down with her to tell her what are our expectations is just she from primary school level..." Another parent stated: "...My child is working hard. We believe in God in whatever she is doing. Here at home, there is no one who sets and communicates high expectations because children are taught at school and teachers know how to teach and they are the ones to prepare the students for future life..."

From the study findings it was found that students who set high expectations and desires in life and who are self-motivated and encouraged regardless of the fact that they are from single-parented families tends to study hard in order to reach the vision for their future life resulting into positive performance.

\section{Conclusion and Recommendation}

Basing on the study findings researchers concluded that despite the fact that single parent students face many challenges in attaining secondary school education but still they are performing well in their studies. Furthermore, the research has identified the factors for positive performance of students from single parent during their study in school including attitude of the students, social circle (surrounding people), self-motivation and encouraging, counseling and guidance services as well as setting of high expectations and desires. 
Based on the study findings, the following are the recommendations for improvement;

1) Parents and community should work together to guide and counsel children on how best to improve academic success.

2) Parents should be sensitized on the importance and good ways of rearing and encouraging their children to attend school.

3) Also, teachers are encouraged to be close to single parent students to understand their problems to advise them on how to keep up with those problems, to give them academic support, and to love them. This will make them comfortable and cared hence the students maintain their positive performance at school.

\section{Conflicts of Interest}

The authors declare no conflicts of interest regarding the publication of this paper.

\section{References}

Akinsola, M. K., \& Olowojaiye, F. B. (2008). Teacher Instructional Methods and Student Attitudes towards Mathematics. International Electronic Journal of Mathematics Education, 3, 60-73.

Amato, P. R. (2010) Research on Divorce: Continuing Trends and New Developments. Journal of Marriage and Family, 72, 650-666. https://doi.org/10.1111/j.1741-3737.2010.00723.x

Amofa, R. (2013). Effects of Single Parenting on Adolescents' Academic Performance. Institute for Development Studies, University of Cape Coast.

Azuka-Obieke, U. (2013). Single-Parenting, Psychological Well-Being and Academic Performance of Adolescents in Lagos, Nigeria. Journal of Emerging Trends in Educational Research and Policy Studies (JETERAPS), 4, 112-117.

Daniel, P. (2010). Psychosocial Well-Being and Relationship between Divorce and Children's Academic Achievement; Journal of Marriage and the Family, 3, 933-994.

Ferrell, R. T. (2009). The Effects of Single-Parent Households on Student Academic Success, Attendance and Suspensions: UMI Microform.

Hoover-Dempsey, K. V., Walker, M. T., Sandler, H. M., Whetsel, D., Green, C. L., Wilkens, A. S., \& Closson, K. (2005). Why Do Parents Become Involved? Research Findings and Implications. Elementary School Journal, 106, 105-130. https://doi.org/10.1086/499194

Jonathan, G. (2004). Is Making Divorce Easier Bad for Children? The Long-Run Implications of Unilateral Divorce. Journal of Labor Economics, 2, 50-72.

Kimwaga, M. D. (2000). The Effectiveness of Guidance and Counseling Service for Street Children: A Case Study of Centers in Dar es Salaam. Masters' Dissertation, University of Dar es salaam.

Kolambe, J. (2016). The Role of Parents and Teachers in Child's Life. The Guardian Reporter; Dar es Salaam.

Malima, J. G., \& Akech, P. E. (2016). The Effect of Single Parenting on Students' Academic Performance in Secondary Schools in Arusha City, Tanzania.

Mazana, M. Y., Montero, C. S. \& Casmir, R. O. (2019). Investigating Students' Attitude towards Learning Mathematics. International Electronic Journal of Mathematics Educa- 
tion, 14, 207-231. https://doi.org/10.29333/iejme/3997

Mrinde, N. J. (2014). Challenges That Single Parented Student's Face in Attaining Secondary School Education. Kindondoni Municipality.

Mutai, K. J. (2011). Attitudes towards Learning and Performance in Mathematics among Students in Selected Secondary Schools in Bureti District, Kenya.

Nyarko, K. (2010). Parental Home Involvement: The Missing Link in Adolescents' Academic Achievement. Educational Research, 1, 340-344.

OECD (2013). Students' Drive and Motivation. Results: Ready to Learn-Students' Engagement, Drive and Self-Beliefs. Volume III. OECD.

https://www.oecd.org/pisa/keyfindings/pisa-2012-results-volume-III.pdf

Ortese, P. T. (1998). Single Parenting in Nigeria Counseling Concerns and Implication. The Counselor, 16, 61-66.

Parisa, R. (2011). The Relationship between Self-Esteem, Achievement Goals and Academic Achievement among the Primary School Students. Procedia-Social and Behavioral Sciences, 29, 803-808. https://doi.org/10.1016/j.sbspro.2011.11.308

Parsons, T. (1951). The Social System. Free Press.

Ponzetti, J. J. (2003). Single-Parent Families. In International Encyclopedia of Marriage and Family (Vol. 4). Macmillan Press.

Redding, S. (2006). The Mega System: Deciding, Learning, and Connecting. Academic Development Institute.

Reynolds, A. R., \& Walberg, H. J. (1992). A Process Model of Mathematics Achievement and Attitude. Journal of Research in Mathematics, 23, 306-328.

https://doi.org/10.5951/jresematheduc.23.4.0306

RITA (2007). The United Republic.

Salami, S. O., \& Alawode, E. A. (2000). Influence of Single-Parenting on the Academic Achievement of Adolescents in Secondary Schools: Implications for Counseling Department of Guidance and Counseling University of Ibadan, Ibadan.

Smith, W. (2008). What Are the Effects on Single Parents? Are Children of Single-Parent Homes Doomed?

http://www.lifescript.com/life/family/parenting/what...of-single-parents.aspx

Stone, A. (2012). Changing Patterns in Family Structure: The Plight of Children in Nigerian Schools. Macmillan Publishers Ltd.

TAMWA (2009). Annual Report.

Unamba, E. C., Okwara-Kalu, C. E., \& Ibe Georgeline, C. (2020). Comparative Study of Levels of Academic Self Esteem and Academic Achievement in Mathematics among Pupils of Two and Single Parent Families. Malikussaleh Journal of Mathematics Learning (MJML), 3, 70-75. https://doi.org/10.29103/mjml.v3i2.3172

Yunus, A. S., \& Ali, W. Z. (2009). Motivation in the Learning of Mathematics. European Journal of Social Sciences, 7, 93-101. 